\title{
Electrochemical Corrosion Behavior of 15Cr-6Ni-2Mo Stainless Steel with/without Stress under the coexistence of $\mathrm{CO}_{2}$ and $\mathrm{H}_{2} \mathrm{~S}$
}

\author{
Xue Hui Zhao ${ }^{1,2, *}$, YaoRong Feng ${ }^{2}$, ShaWei Tang ${ }^{3}$, JianXun Zhang ${ }^{1}$ \\ ${ }^{1}$ School of Materials Science and Engineering, Xi an Jiaotong University, Xi an 710049, China \\ ${ }^{2}$ State Laboratory for performance and Structure Safety of Petroleum Tubular Goods and Equipment \\ Materials, CNPC Tubular Goods Research Institute, xi an 710077, China \\ ${ }^{3}$ School of Materials Science and Engineering, Harbin Institute of Technology, Harbin 150001, China \\ *E-mail: zhaoxuehui@cnpc.com.cn
}

doi: $10.20964 / 2018.07 .59$

Received: 6 February 2018 / Accepted: 23 March 2018 / Published: 5 June 2018

\begin{abstract}
An electrochemical study was performed on $15 \mathrm{Cr}-6 \mathrm{Ni}-2 \mathrm{Mo}$ stainless steel to evaluate its corrosion behavior. The specimens in the present study were divided into two groups: with and without applied stress. Three conditions were considered and showed significant influence on the corrosion behavior of $15 \mathrm{Cr}-6 \mathrm{Ni}-2 \mathrm{Mo}$ steel. When the conditions of coexisting $\mathrm{CO}_{2}$ and $\mathrm{H}_{2} \mathrm{~S}$ were changed, the passivation state of the material surface had obvious differences. Applied stress decreased the corrosion potential and pitting potential and increased the pitting sensitivity of the materials. The influence of $\mathrm{H}_{2} \mathrm{~S}$ on the corrosion resistance of materials under stress was more obvious.
\end{abstract}

Keywords: Stainless Steel, Polarization curves, Stress corrosion, Corrosion Behavior, Pitting potential

\section{FULL TEXT}

(C) 2018 The Authors. Published by ESG (www.electrochemsci.org). This article is an open access article distributed under the terms and conditions of the Creative Commons Attribution license (http://creativecommons.org/licenses/by/4.0/). 